\title{
How to Select a Location and a Design of Measures on Land Drainage - A Case Study from the Czech Republic
}

\author{
Antonín Zajíček ${ }^{1 *}$, Tomáš Hejduk' ${ }^{1}$ Libor Sychra² ${ }^{2}$ Tomáš Vybíral ${ }^{3}$, Petr Fučík ${ }^{1}$ \\ 1 Research Institute for Soil and Water Conservation, v.v.i., Žabovřeská 250, 15627 Prague 5, Zbraslav, \\ Czech Republic \\ 2 Sweco, Hydroprojekt a.s., Táborská 31, 140 16, Prague 4, Czech Republic \\ ${ }^{3}$ GEOREAL spol. s r.o., Hálkova 12, 30100 Plzeň, Czech Republic \\ * Corresponding author's email: zajicek.antonin@vumop.cz
}

\begin{abstract}
A new approach for sites prioritization and designing measures on land drainage was developed and tested on the $96.5 \mathrm{~km}^{2}$ Žejbro catchment (Czech Republic). The aim was to design an effective, mutually interconnected system of measures, on tiles, manholes, outlets as well as on ditches (s.c. main drainage facilities, MDF) that will increase water retention and storage in intensively farmed and tile-drained catchments and will reduce water pollution from subsurface non-point sources (drainage runoff). This approach consists of (I) selecting suitable sites using the Catchment Measures Need Index (CAMNI) method; (II) obtaining information on land drainage in the area of interest; (III) conducting a field survey and water quality monitoring; (IV) designing appropriate systems of measures; and (V) analysing the estimated costs of the proposed measures. Measures were proposed for fourteen sub-catchments that were selected based on the results of a CAMNI analysis and whether an MDF or a heavily modified stream is present. A total of 44 point measures, 62 areal measures, and 99 line measures were proposed. Implementation of these measures would reduce the load of $\mathrm{N}^{-\mathrm{NO}_{3}}$, a major pollutant from drainage runoff, by 44 tons per year (48\%). From the financial point of view, these measures are not self-financing and the benefits do not cover the expected costs of their implementation and maintenance. However, these measures have a profound ecological and societal benefits which, when taken into account, make these measures suitable for implementation when (co-)financed from public budgets. Putting the presented approach into practice, for example, in the framework of complex land consolidations or by watershed management authorities, could significantly improve the condition and water regime of intensively drained agricultural landscapes.
\end{abstract}

Keywords: agricultural drainage, main drainage facility, water pollution, prioritization and design of measures, revitalization.

\section{INTRODUCTION}

Agricultural drainage systems are a typical and integral element of the cultural agricultural landscape of the Czech Republic (CR). The tradition of land drainage in this region dates back to the $2^{\text {nd }}$ half of the $19^{\text {th }}$ century [Kulhavý and Fučík, 2015]. Typical agricultural drainage systems, which were mainly built in the period from 1960 to 1980, take the form of areal subsurface tile drainage - detailed drainage facilities (DDFs) which are connected to the drainage ditches (open or tubed) - main drainage facilities
(MDFs). Currently, there is approximately 1.1 million ha of drained land in CR [Kulhavý et al., 2007], which is more than $25 \%$ of all agricultural land. Also, according to the records of the Czech State Land Office, there are almost $9000 \mathrm{~km}$ of MDFs in form of drainage channels, of which almost two thirds $(5200 \mathrm{~km})$ are open canals and the remaining third (3800) are tubular sections. Such large areas of drained land are associated with some negative impacts on the landscape, especially in areas where the area intensity of the drainage is too high and in locations where drainage is redundant or no longer desirable. Drainage 
systems act as continuous horizontal preferential pathways in the soil that are deliberately sized to carry large quantities of water away from the drained area. This greatly accelerates the overall runoff from the landscape. Drainage primarily affects shallow subsurface, surface, and groundwater runoff regimes and the water balance of the unsaturated zone. Subsequently, the water regime receiving the drainage water is also affected, particularly in the case of watercourses. Accelerated runoff is also associated with increased leaching of certain substances from the soil. Drainage systems are a significant source of agricultural pollution, especially nitrate-nitrogen [Fučík et al., 2017], pesticides [Zajíček et al., 2018a; Brown \& van Beinum, 2009] and their metabolites, and soluble forms of phosphorus. MDFs also have some negative landscape impacts. In the case of open ditches, the characteristics that are considered to be negative are similar to those of other types of artificial watercourses. These include, in particular, the altered directional and elevation conditions, flow capacity, fortification method, and maintenance status [Kulhavý et al., 2012; Dollinger et al., 2015; Kozelová et al., 2020]. Embedding and straightening the drainage line affects the runoff process and lowers the groundwater level (GWL) on adjacent land. In the case of tubular MDFs, there is a loss of stream connectivity to adjacent lands as well as a loss of natural filtration and groundwater recharge. The proposals for reshaping open channels into tubular sections have been amenable to the interest of consolidating land into larger production blocks and have reflected local conditions only in terms of the accessibility of these land blocks, often without taking into account the hydrological characteristics of the area. Often, drainage systems divert more water from agricultural land than what would be desirable from the agricultural point of view or water management point of view. This is because of the excessive intensity of the drainage and the absence of dual-function systems with drainage runoff management. In general, overly intensive drainage has led to a decline in landscape biodiversity due to the destruction of the habitats of certain animal and plant species [Stoate et al., 2009]. Another problem with drainage structures that is often discussed nowadays in CR and elsewhere is their functionality and state. The systems were usually designed to last for 40 years. Although the current condition of drainage structures is generally not good and is continuously deteriorating, most systems are still functional. Failures are mainly caused by localised waterlogging, making it difficult to cultivate the land. On the other hand, long-term neglect of these structures increases the costs of maintaining the fertility of the land and thus reduces the efficiency of crop production and, consequently, the price of the land [Kulhavý and Fučík, 2015].

The option for mitigation the negative effects of intensive land drainage in the landscape is to propose and implement various types of measures or carry out their revitalization. Revitalisation measures on MDFs and heavily modified streams should restore the natural state of the riverbed and the adjacent banks. Increasing the roughness and lengthening the flow path or installation of low weirs can slow the runoff from the area, increase the self-cleaning capacity of the stream and at least partially restore the habitats naturally occurring along the watercourses as part of the landscape skeleton [Lüderitz, 2004; Váchal et al., 2006; Kroger et al., 2008].

The aims of this paper are to introduce an innovative approach to prioritize and designing effective measures for main and detailed drainage facilities to increase water retention and accumulation and reduce water pollution in agricultural catchments and to demonstrate the use of this approach in the pilot area.

\section{MATERIALS AND METHODS}

\section{Pilot locality}

The approach to designing revitalisation measures was tested on the Žejbro pilot site (Figure 1a). It is a catchment that has been monitored for more than 30 years, located in the Chrudim district near the town of Skuteč. Geomorphologically, the area mainly falls into the subprovince of the Czech Tableland. In the source area, it also extends into the subprovince of the Bohemian-Moravian Highlands. The whole pilot area is $96.5 \mathrm{~km}^{2}$ and it consist of 12 catchments of $4^{\text {th }}$ order.

The terrain is rugged with a surface sloping from SW to NE and characterised by countersunk valleys. The character of the highlands gradually changes to a hilly area towards the north. Altitudes range from 340 to $676 \mathrm{~m}$ above sea level.

The geological substrate is mainly phyllites, phyllitised shales, grits, and siltstones. The Quarternary sediments consists of sandy-clay eluvial 
sediments up to 2 meters thick. The soil cover is very diverse due to the size and ruggedness of the area. In total, there are 19 main soil groups with the following soils prevailing: Haplic Gleysols (28.5\%), Stagnic and Haplic Cambisols (25\%), and acid to podzolic soils (6.7\%). A total of $35.5 \%$ of the soils are not agricultural, which we do not classify here.

The area is intensively used for agriculture (Figure 1b), predominantly for the cultivation of cereals (oats, wheat, maize) and oilseed rape. The pattern of the drainage system consists of a total of 7 MDFs and many long sections of the stream's channels modified to MDF form. However, in the individual catchments of the $4^{\text {th }}$ order, this proportion varies from 0.0 to $53.8 \%$ of the territory. Large scale drainage is particularly characteristic of the catchment areas of the Kotelský and Dolský streams, which are part of the Žejbro catchment area. The large proportion of drained areas in the form of tile areal tile drainage poses a significant risk of water pollution from subsurface sources. The proportion of drained land is $17.6 \%$ of the total area.

\section{METHODOLOGY}

The initial idea was to propose measures which would improve the role of the MDFs in the landscape, particularly in terms of slowing runoff from the site, enhancing the self-cleaning capacity of the stream, and reducing nutrient transport by subsurface (tile-drainage) runoff. On the other hand, agricultural production should be preserved. The procedure for designing the measures is described in several sequential steps, which are shown in the flowchart in Figure 2.

\section{Selecting vulnerable areas}

For financial and ecological efficiency, the measures should be targeted where they will have the greatest effect, that is, in the locations most affected by the change in the water regime following the construction of the agricultural drainage systems, which are also at risk of increased nutrient and pollutant leaching.

The classification of the area in terms of threat from sub-surface sources of pollution was

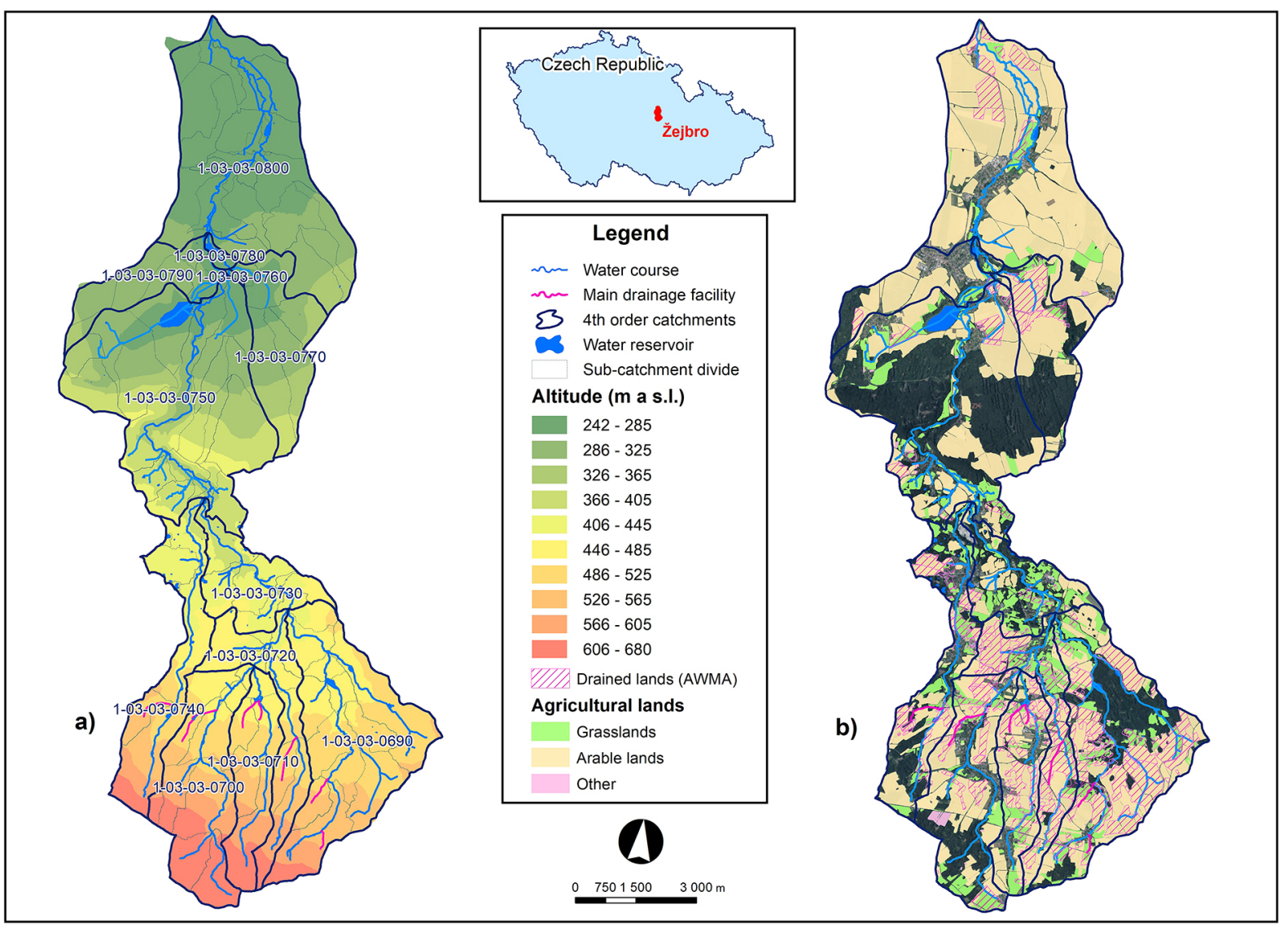

Figure 1. Location and overview of the pilot site Žejbro; a) Altitude and hydrology, b) Land use and drained areas 


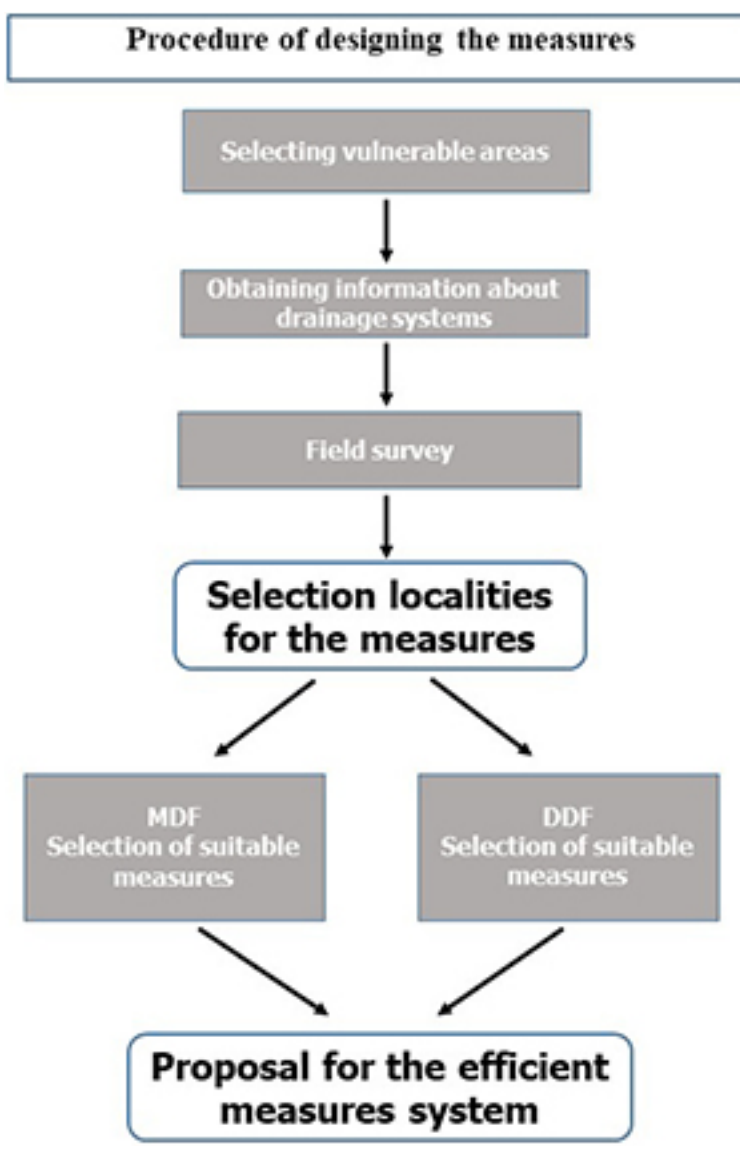

Figure 2. Procedure of designing the revitalisation measures

carried out using an index assessment of the area. The index assessment was based on five indexes that classify factors that both reduce and increase the risk of exposure of assessed area (the $4^{\text {th }}$ order catchments or the sub-catchments) to subsurface sources pollution.

This method was developed to deal with area subsurface sources of pollution in cooperation with the Vltava River Basin State Enterprise [Novák et al., 2016]. In practice, a slightly modified method was used in the subsurface (drainage) pollution risk in published in the online map browser [Zajíček et al., 2018b].
The Index of arable land proportion is based on the assumption that the risk of water pollution increases with increasing proportion of arable land [Worrall et al., 2003, Fučík et al., 2014].

The Index of drained area proportion is based on the assumption that the risk of water pollution increases as the proportion of agricultural drainage in the assessed area increases [Hirt et al., 2005; Zajíček et al., 2018b].

The Index of vulnerable soils proportion (in term of the infiltration rate) is based on the assumption that as the proportion of soils with high infiltration capacity for water (i.e. also vulnerable to nutrient leaching) increases in the assessed area, the risk of water pollution increases [Goswami et al., 2009; Fučík et al., 2015]. Classification of soils based on their permeability to water and nutrients was performed according to the methodology of [Janglová et al., 2003].

The Index of grassed vulnerable soils proportion (in terms of the infiltration rate) reflects the effect of grassing as an already implemented measure that significantly reduces nutrient [Kvítek et al., 2009, Zajíček at al., 2017] and pesticide parent compounds [Zajíček et al., 2018a] leaching from agricultural soils.

The Index of water reservoir improvement was chosen based on the fact that the resulting water quality in water bodies is also influenced by the self-cleaning process. This process takes place in the environment of the whole catchment (thus mitigating the influence of area sources of pollution) as well as in the streams and reservoirs themselves. The classification of the index was based on the assumption that, in general, the risk of water pollution decreases as the proportion of water bodies in the assessed area increases.

In the end, the Catchment Measures Need Index (CAMNI) was determined for each assessed site (catchment area of the $4^{\text {th }}$ order, subcatchment area). The CAMNI value was assigned a risk level (RL-CAMNI) 1 to 5 , where level 1 represents a negligible risk without the need for

Table 1. The assessment of particular CAMNI risk levels

\begin{tabular}{|c|c|c|}
\hline \multirow{2}{*}{ Risk levels - CAMNI } & \multicolumn{2}{|c|}{ Verbal assessment: } \\
\cline { 2 - 3 } & Risk levels & Necessity of measures \\
\hline 1 & Negligible risk & No need of measures \\
\hline 2 & Small risk & Small need of measures \\
\hline 3 & Moderate risk & Moderate need of measures \\
\hline 4 & Significant risk & Significant need of measures \\
\hline 5 & Very significant risk & Very significant need of measures \\
\hline
\end{tabular}


designed/proposed measures and level 5 represents a very significant risk, respectively, with a very significant need for designed/proposed measures on the evaluated site (Table 1).

\section{Obtaining detailed information about drainage systems}

In order to design measures that will minimise the negative effects of drainage systems and promote their positive effects, it is necessary to know the exact course of the MDF and the location of the DDF elements of surface drainage (especially drains and drainage outlets), as well as their basic technical characteristics and current physical condition. As a base, the vector DDF layer created by former Agricultural water management authority (AWMA) was used. Although obsolete, this layer represents unique data about drainage systems in the whole Czech Republic. For making these data more accurate, historical plans of drainage systems in the pilot locality were obtained (mainly from the archive of the Labe Watershed Management Authority). The plans obtained were scanned, spatially oriented (georeferenced), and vectorised using ArcGis software.

\section{Conducting the field survey}

The field survey aimed to verify and supplement the obtained data on the location of the drainage structures. The condition of the identified MDFs was examined in detail, drainage outlets and manholes were identified, and local failures of DDFs were identified. The field survey also included the water quality monitoring of DDFs (4 gauge profiles), MDFs (5 gauge profiles), and surface streams (5 gauge profiles). Its purpose was to confirm the accuracy of the categorisation of the sub- catchments in the area of interest in terms of the vulnerability to non-point agricultural pollution sources using CAMNI and to provide a basis for estimating the current nitrate-nitrogen removal and the potential effectiveness of the proposed measures. The survey was conducted over a three-year period with water samples collected manually at monthly intervals. Nitrate nitrogen as well as total and dissolved reactive phosphorus concentrations were monitored.

\section{Designing the measures}

When actually designing the measures, the connection between the MDF and the DDFs was respected as well as sub-catchment divides and measures were designed in hydrologically continuous systems. Measures designed in hydrologically continuous systems of measures are more efficient in terms of function and cost than solitary measures distributed irregularly in the landscape. The aim of the proposed measures was to return to, or at least bring the watercourses and MDFs closer to, their natural state while maintaining the intensive agricultural production that takes place in the area. At the same time, measures were proposed for the DDFs with the main objective of reducing the input of pollutants leaching from the soil into surface water streams while slowing the runoff of shallow subsurface water from the site. The selection of appropriate MDF measures was based on a catalogue of measures published by Pavel et al. [2019]. The selection of revegetation measures on modified streams and DDFs was based on the catalogue of measures published by Kulhavý et al. [2017]. Most of measures chosen from these national catalogues are also described in the international "Natural Water retention measures cataloque" [http://nwrm.eu/measures-catalogue] and Global Database on Sustainable Land Management - WOCAT [https://www.wocat.net/ en/global-slm-database].

\section{Assessing the measures' efficiency}

The assessment of the effectiveness of measures in reducing pollution from sub-surface sources was carried out on the basis of an empirical calculation. Firstly, the contribution of drainage systems to the total water pollution in the evaluated sites in the current situation was determined. To calculate the current nitrogen load, the following quantities were used: drained area in each sub-catchment, land use in the areas with drainage systems (according to LPIS), the size of the specific drainage runoff (based on direct measurements in the pilot area and long-time monitoring of drainage systems in drainage systems with similar geographic conditions - [Fučík et al., 2017, Zajíček et al., 2016, 2018a], and N-NO concentration values (assigned to each CAMNI risk level value on the basis of a field survey). The effectiveness of individual measures to reduce sub-surface water pollution was determined 
on the basis of a detailed study of literature [Addy et al., 2016; Povilaitis et al., 2018; Carstensen et al., 2020; Lavrnić et al., 2020], and on the basis of direct measurements of the effectiveness of measures at the experimental sites of VÚMOP, v.v.i. [Kulhavý and Fučík, 2015; Zajíček et al., 2017; Vymazal et al., 2020]. Estimated efficiency for selected most often proposed measures is given in the Table 2.

The measures relevant to reducing sub-surface pollution were selected in the GIS environment to calculate the effectiveness of the proposed measures. The area that the measure will influence after its implementation was delimited for each relevant measure. For unaffected areas, the calculation of leaching out remains unchanged. For the areas affected, a new calculation is carried out in such a way that a runoff is reached, which is percentage-wise reduced according to the effectiveness of the measures for reducing the drainage runoff, and the concentration of $\mathrm{N}^{-\mathrm{NO}_{3}}$ is reduced based on estimates of the effectiveness of the proposed measures.

\section{Financial evaluation of the measures}

The unit costs of the proposed measures are based on average prices in the Czech Republic. The average exchange course Czech Crown 26 to EUR 1 was used for readability. Main component of the costs of the measures for the revitalisation of the MDFs is the earthworks associated with the creation of a new channel and the removal of the old one or with the uncovering of the obstructed part of the channel; the method of dealing with the existing fortification, the new necessary fortification, preferably of a pliable nature, the cost of the material forming the subdivision; and its placement in the channel, the implementation of new drains (pipes). The actual unit costs may vary according to the size of the channel addressed by the MDF or the form of the MDF-regulated flow. In the case of an MDF or a small stream, depending on other accompanying measures, the costs may range from EUR 38 to EUR 115 for $1 \mathrm{~m}$ of the section to be treated, with the usual costs being around EUR 3/ for $1 \mathrm{~m}$, as shown in

Table 2. Estimated efficiency of selected measures on drainage runoff and nitrate nitrogen load

\begin{tabular}{|c|c|c|c|c|}
\hline \multirow{2}{*}{ Measure } & \multicolumn{2}{|c|}{ Decrease in drainage runoff } & \multicolumn{2}{|c|}{ Decrease in $\mathrm{N}-\mathrm{NO}_{3}$ load } \\
\hline & $\min -\max (\%)$ & average $(\%)$ & $\min -\max (\%)$ & average $(\%)$ \\
\hline Uncovering the tubular section of MDF & $10-30$ & 20 & $25-50$ & 35 \\
\hline Transfer of drainage waters (scale of MDF) & $75-100$ & 87 & $25-75$ & 50 \\
\hline Controlled runoff from spring sump (with protective grassing) & $50-75$ & 70 & $25-75$ & 50 \\
\hline Local (partial) elimination of drain & $25-75$ & 50 & $25-75$ & 50 \\
\hline Total elimination of drainage & $50-100$ & 75 & $25-75$ & 50 \\
\hline Decreasing of drainage intensity - curtain & $15-65$ & 40 & $15-65$ & 40 \\
\hline Small pool connected to drainage & $10-50$ & 25 & $10-25$ & 15 \\
\hline Root bed treatment system at the outlet of drainage system & $10-25$ & 15 & $10-50$ & 25 \\
\hline Biofilter related to drainage system & $10-25$ & 15 & $40-80$ & 60 \\
\hline Local transfer of drainage waters (scale of DDF) & $25-75$ & 50 & $25-75$ & 50 \\
\hline Controlled drainage & $25-75$ & 50 & $25-75$ & 50 \\
\hline Infiltration drain & $25-100$ & 50 & $50-90$ & 75 \\
\hline Wetland at the outlet of drainage system & $10-25$ & 15 & $50-99$ & 65 \\
\hline Grassing of the infiltration area & $5-10$ & 7 & $40-80$ & 60 \\
\hline
\end{tabular}

Table 3. Unit costs for the investment and the maintenance of the most common measures on the main drainage facilities

\begin{tabular}{|l|c|c|c|}
\hline \multicolumn{1}{|c|}{ Type of measure MDF } & Unit & Investment/ unit $(€)$ & Maintenance/unit/year $(€)$ \\
\hline Uncovering the tubular section of MDF & $\mathrm{m}$ & 23.0 & 70 \\
\hline MDF channel revitalisation & $\mathrm{m}$ & 77.0 & 80 \\
\hline Small stream revitalisation & $\mathrm{m}$ & 134.5 & 100 \\
\hline Transfer of drainage waters (scale of MDF) & $\mathrm{m}$ & 19.2 & 10 \\
\hline Linear foliage & $\mathrm{m}$ & 5.8 & 45 \\
\hline
\end{tabular}


Table 4. Unit costs for the investment and the maintenance of the most common measures on the main drainage facilities

\begin{tabular}{|l|c|c|c|}
\hline \multicolumn{1}{|c|}{ Type of measure DDF } & Unit & Investment/unit $(€)$ & Maintenance/unit/year $(€)$ \\
\hline Controlled runoff from spring sump (with protective grassing) & piece & 3080 & 22 \\
\hline Local (partial) elimination of drain & piece & 14 & $\mathrm{n}$ \\
\hline \multirow{2}{*}{ Total elimination of drainage } & $\mathrm{m} / \mathrm{ha}$ & $11 /$ & \multirow{2}{*}{$\mathrm{n}$} \\
\cline { 3 - 4 } & & 19230 & $\mathrm{n}$ \\
\hline Decreasing of drainage intensity - curtain & piece /ha & $14 / 770$ & \multicolumn{2}{|c|}{30} \\
\hline Small pool connected to drainage & $\mathrm{m}^{3}$ & 400 & 3600 \\
\hline Root bed treatment system at the outlet of drainage system & piece & 100000 & 46 \\
\hline Biofilter related to drainage system & piece & 400 & 2 \\
\hline Local transfer of drainage waters (scale of DDF) & $\mathrm{m}$ & 150 & $0.01 / 38$ \\
\hline Controlled drainage & $\mathrm{m} / \mathrm{ha}$ & $15 / 21923$ & 0.01 \\
\hline Infiltration drain & $\mathrm{m}$ & 6 & 4250 \\
\hline Wetland at the outlet of drainage system & ha & 3850 & 250 \\
\hline Grassing of the infiltration area & ha & 3080 & \\
\hline
\end{tabular}

Table 3. Unit prices for measures on DDFs vary according to the type of the particular measure and are shown in Table 4.

\section{RESULTS AND DISCUSSION}

\section{Delimiting areas suitable for designing measures}

The first step when selecting sites suitable for designing measures was to analyse the area in terms of the need for measures - that is, sites where water quality and retention are threatened by intensive subsurface (drainage) runoff. CAMNI analysis was used for this step at two special levels. First, CAMNI analysis was performed on scale of the $4^{\text {th }}$ order catchments. The results are presented in Figure 3a. Three (out of a total of twelve catchments in the pilot area) were assigned to CAMNI risk level 4 (significant need of measures) and two catchments to CAMNI risk level 5 (very significant need of

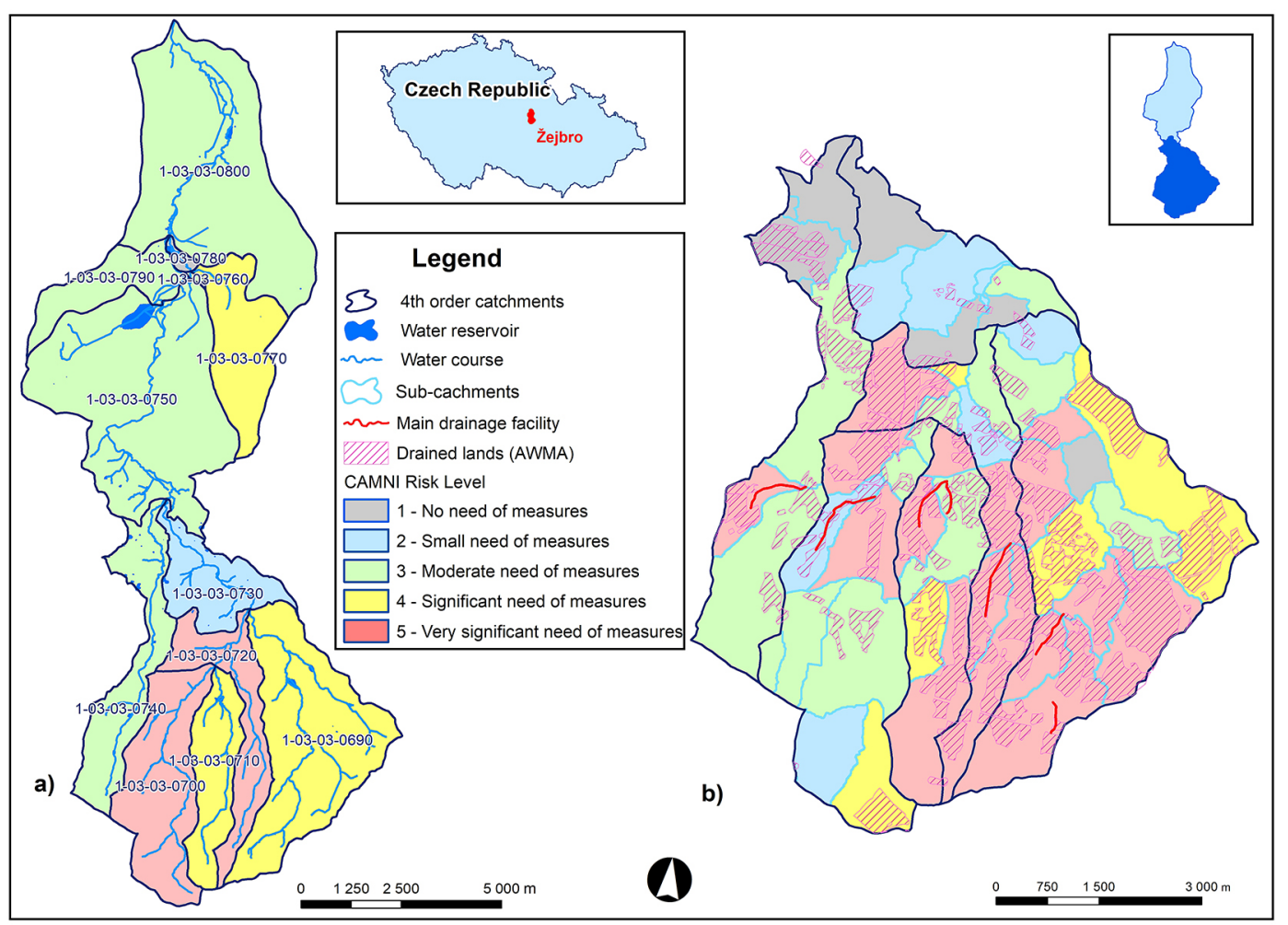

Figure 3. Results of CAMNI analysis; a) scale of the 4th order catchments, b) scale of sub-catchments 
measures). These catchments are mainly located in the southern, source part of the catchment. Therefore, further investigation was focused mainly on this part of the catchment. More precise identification of sites in term of necessity measures proposal was carried out at the spatial scale of the sub-catchments. The results are presented as a graph in Figure 3b. Of the 105 sub-catchments assessed, a total of 36 subcatchments were assessed as having a significant or very significant need of measures. The vast majority of these sub-catchments, vulnerable to pollution from subsurface area sources, are again located in the southern part of the pilot area. In general, these are sites that, in addition to intensive drainage, are also characterised by a high proportion of ploughing lands and the existence of soils with low water retention capacity in their source areas.

\section{Obtaining drainage system data for the area of interest}

The second step was to obtain detailed documentation for all the drainage structures. All collected data are depicted in the Figure 4a. A total of seven MDFs were identified and digitised in the southern (source) part of the pilot site, which, along with some modified streams, form the drainage pattern of the locality. Data from AWMA were pecified by the building planes of DDFs. Approximately $60 \%$ of the DDF project documentations in the pilot site were found and subsequently digitised (scanned, georeferenced, and vectorised). An example of georeferenced DDF building plane is shown in Figure 4b. An example of vectorised drainage system data is shown in Figure 4c. The archival documentation provided a valuable basis for the identification of the structures, even though they do not always fully correspond in area and shape to the reality on the field. That is why the true location and extent of the drainage structures should be verified using remote sensing and field survey methods [Tlapáková et al., 2015, 2017].

\section{Conducting the field survey}

Within the field survey, a reconnaissance of the drainage MDFs and DDFs in sub- catchments identified as vulnerable to subsurface sources of pollution-that is, with a high need for design measures-was carried out. The present condition of the identified MDFs was examined in detail. Drainage outlets and manholes were identified and localised, as were local DDF failures.

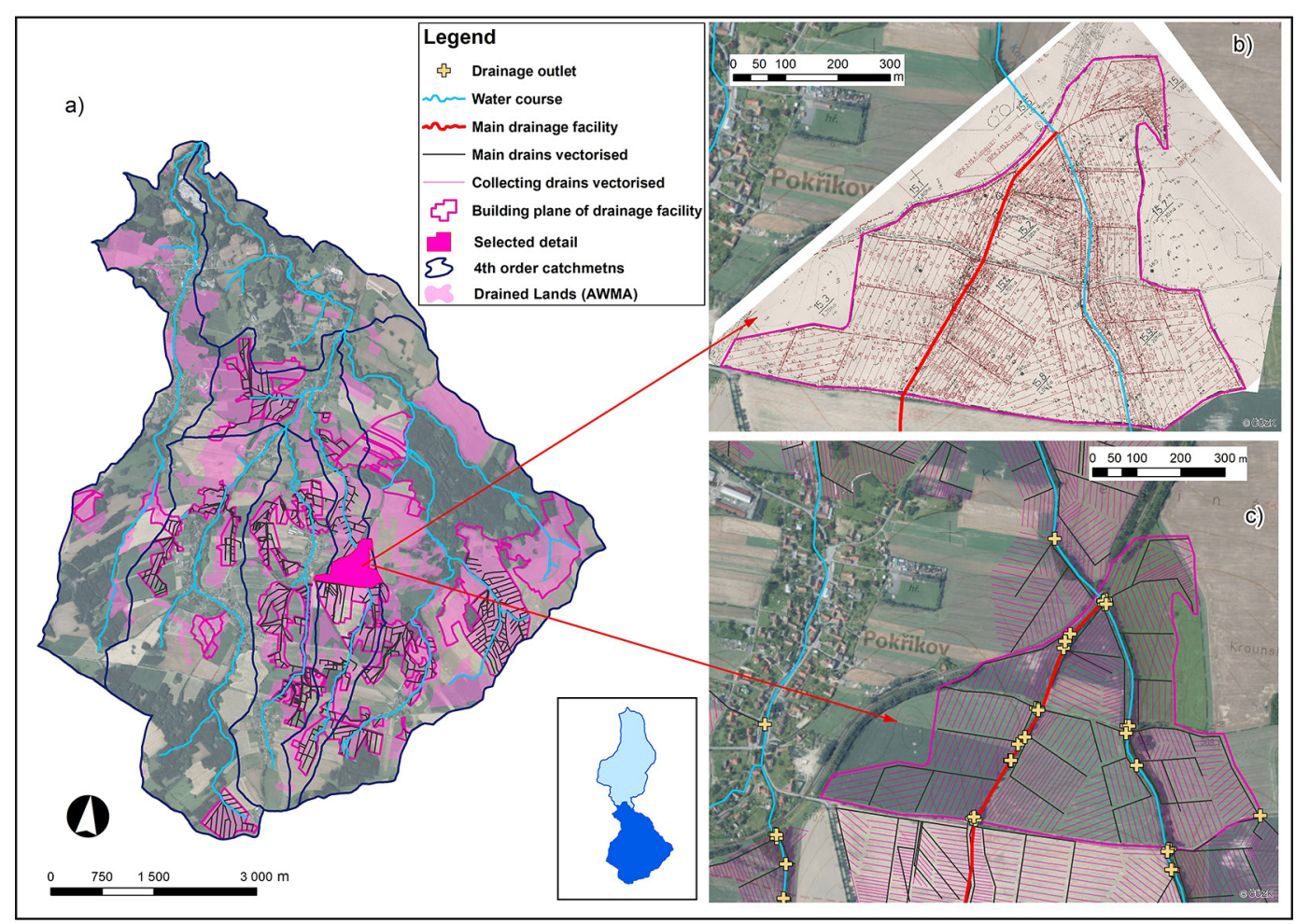

Figure 4. Obtained data about drainage system in the pilot area; a) Collected drainage systems data, b) Examples of rectified DDF building plan, c) Example of vectorised drains and outlets 
The field survey also included monitoring water quality in drainage waters, MDF water, and stream water. The results of the monitoring showed a very high load of surface agricultural pollution in the waters, especially nitrate-nitrogen with a median concentration of $19.9 \mathrm{mg} / \mathrm{l}$. The considerable variability in $\mathrm{N}^{-\mathrm{NO}_{3}}$ concentrations (from 0.4 to $65.8 \mathrm{mg} / \mathrm{l}$ ) can mainly be explained by the variable magnitude of flow and crop composition or fertilisation during crop rotation. Nitrate-N concentrations also varied by water type (higher concentrations in MDF and drainage waters demonstrate the importance of subsurface $\mathrm{N}$ leaching). The highest $\mathrm{N}-\mathrm{NO}_{3}$ concentrations in the area of interest were measured in drainage waters and MDF waters with a CAMNI risk index value of 5, where the mean value was $29.9 \mathrm{mg} / \mathrm{l}$ and the median value was $28.1 \mathrm{mg} / 1$. In drainage and MDF waters in sub-catchments with CAMNI index risk levels of 2-3, the median values of $\mathrm{N}^{-\mathrm{NO}_{3}}$ concentrations were $19.3 \mathrm{mg} / \mathrm{l}$. Based on these results, concentrations typical of each CAMNI risk level (from 5 to $30 \mathrm{mg} / \mathrm{l}$ ) could then be determined. These values, detailed in the Table 5, were further used to estimate the subsurface (drainage) runoff load and the effectiveness of the proposed measures. Table 5 also presents the values of specific $\mathrm{N}-\mathrm{NO}_{3}$ load. The average annual nitrate-nitrogen load from 1 ha of drained area was determined to be $64 \mathrm{~kg} /$ year and from 1 ha of sub- catchment, 18 $\mathrm{kg} / \mathrm{ha}$. Based on the above results and the predicted nitrate-nitrogen load values, sub-catchments with CAMNI risk levels 4 and 5 occupy $42 \%$ of the pilot area but are responsible for $83 \%$ of the nitrate-nitrogen load to water from subsurface sources. Therefore, these sub-catchments are the sites where measures need to be targeted.

The concentration and $\mathrm{N}-\mathrm{NO}_{3}$ load estimated at the Žejbro site are similar to the results at other long-term monitored agricultural drained sites [Fučík et al., 2014, 2017], confirming the accuracy of the categorisation of the area by the CAMNI method.
Based on the assessment of the results of the analysis of the need for action proposals (CAMNI risk level), the presence of an MDF or heavily modified stream in the study area, and the findings of the field survey and local problems identified, 14 sub-catchments were targeted for the actual action proposals.

\section{Designing the measures}

In the selected 14 sub-catchments, systems of measures were proposed on MDFs with the aim of restoring or at least bringing the watercourses closer to their natural state while maintaining the intensive agricultural production that takes place in the area. Consequently, measures on DDFs were proposed with the main objective of reducing the input of pollutants that leach from the soil into surface watercourses while, at the same time, slowing down the runoff of shallow subsurface water from the site. An overview of the location measures proposed is presented in the Figure 5a. The focus was to propose both types of measures (on MDFs and on DDFs) as one system. Otherwise, the measures would not only lose their proper effect, but in some cases, they may also be counterproductive [Tlapáková et al., 2015].

A summary of the proposed measures is given in the Table 6 . The point measures were mainly targeted at or adjacent to drainage outlets. A total of 44 point measures were proposed on DDFs and drainage outlets, including 40 biofilters and 4 root bed treating systems.

Linear measures were mainly targeted at revitalising MDFs and streams. However, measures such as re-opening and removing drains or decreasing of drainage intensity were also proposed. Among the linear measures proposed were re-opening mainly tubed MDFs: $1317 \mathrm{~m}$, re-opening tile drains: $2823 \mathrm{~m}$, and channel revitalisation (both stream and MDF): $5816 \mathrm{~m}$.

Table 5. Estimated N-NO 3 concentrations and loads assigned to particular CAMNI risk level within the pilot area of Žejbro catchment

\begin{tabular}{|c|c|c|c|c|}
\hline \multirow{2}{*}{$\begin{array}{l}\text { CAMNI risk } \\
\text { level }\end{array}$} & \multicolumn{2}{|c|}{$\mathrm{N}-\mathrm{NO}_{3}$ concentration } & \multicolumn{2}{|c|}{$\mathrm{N}-\mathrm{NO}_{3} \mathrm{z}$ year load from 1 ha area } \\
\hline & Grasslands (mg/l) & Arable lands $(\mathrm{mg} / \mathrm{l})$ & Sub-catchment (kg/year) & Drained area (kg/year) \\
\hline 1 & 5 & 10 & 2.1 & 16.6 \\
\hline 2 & 8 & 15 & 3.3 & 34.5 \\
\hline 3 & 10 & 20 & 8.2 & 56.3 \\
\hline 4 & 15 & 25 & 24.7 & 83.1 \\
\hline 5 & 20 & 30 & 71.4 & 167.3 \\
\hline
\end{tabular}


Areal measures were mainly proposed directly on MDFs or on streams acting as drainage water recipients. These were mainly pools serving to slow down runoff and reduce pollution while simultaneously fulfilling ecosystem functions, and they were designed mainly at drainage outlets. A total of 40 small pools were designed, covering an area of 1.6 ha. Among other measures, a total of 12 wetlands at the outlet of drainage system were proposed in the suitable locations, covering an area of approximately 2 ha. Other areal measures directly targeted the area of the sub-catchments concerned. These are primarily grassing of the source (infiltration) area, which mainly aims to reduce pollution from subsurface runoff. In addition, several measures were proposed that primarily target erosion and runoff reduction - that is, grassed protective strips (4) and grassed waterways (16) also partially targeting subsurface runoff.

\section{A detailed description of measure design}

Sub-catchment 91 (Figure 5b) was selected for a detailed description of how the measures were designed. This site of 72 ha was very intensively tile-drained $(65 \%$ of the total sub-catchment area). The DDF systems are discharged into the MDF $1140 \mathrm{~m}$ long MDF, tubed in the upper (southern) part. The tubing has allowed the creation of a large soil block and the ploughing of what was previously mainly grassland. This soil block is often used for maize cultivation. The adjacent open section of the MDF consists of a trapezoidal profile channel with steep slopes and without any transverse objects. The high capacity of the channel causes rapid drainage of surface water and drainage water. The riparian vegetation consists of isolated groups of trees and shrubs. Previously, the banks of the channel were mowed once a year (to prevent the attachment of woody debris), but at the time of the survey, the unshaded channel was shaded and overgrown with woody debris.

To design proper measures, it was necessary to obtain and spatially orient the situations of the adjacent DDFs. Due to intensive drainage and agricultural use, this sub-catchment was classified as an area with a very significant need of measures based on the CAMNI index (risk level 5). The $\mathrm{N}-\mathrm{NO}_{3}$ load was set to $8.7 \mathrm{~kg} /$ year, and $\mathrm{N}-\mathrm{NO}_{3}$ concentrations ranged from 50 to $66 \mathrm{mg} / 1$ (the average value was $56 \mathrm{mg} / \mathrm{l}$ ).

On the basis of the above findings, the measures were designed. For the southern part of the facility, it was proposed to re-opening the MDF tubular section's entire length (approximately 550 $\mathrm{m})$. The technical design of the measure is limited by the spacing of the drains on the right and left banks of the future channel, which is only about $8 \mathrm{~m}$. In case of a broader intervention, it would be necessary to decide what to do with these drains even after construction. This solution would entail higher investment costs, and for these reasons, it is not a priority. The defined space of $8 \mathrm{~m}$ is sufficient to re-open the MDF in this section. As a complementary measure, grassed protective (buffer) strips will be implemented on both sides of the newly created channel in conjunction with re-opening the pipeline.

In the northern part of the site, where the MDF is already an open ditch, a flow-through small pool with a maximum water depth of $1 \mathrm{~m}$

Table 6. Measured proposed in 14 selected sub-catchments

\begin{tabular}{|c|c|c|c|c|}
\hline \multicolumn{2}{|r|}{ Type of Measure } & \multirow{2}{*}{$\begin{array}{c}\text { Number } \\
40\end{array}$} & \multirow{2}{*}{$\frac{\text { Area }\left(\mathrm{m}^{2}\right)}{\mathrm{n}}$} & \multirow{2}{*}{$\frac{\text { Length }(\mathrm{m})}{\mathrm{n}}$} \\
\hline & Biofilter related to drainage system & & & \\
\hline & Root bed treatment system at the outlet of drainage system & 4 & $\mathrm{n}$ & $\mathrm{n}$ \\
\hline \multirow{5}{*}{ Areal } & Wetland at the outlet of drainage system & 12 & 20413 & $\mathrm{n}$ \\
\hline & Small pool connected to drainage & 40 & 16047 & $\mathrm{n}$ \\
\hline & Grassing of the infiltration area & 2 & 58209 & $\mathrm{n}$ \\
\hline & Grassing - protective strips & 4 & 45770 & $\mathrm{n}$ \\
\hline & Grassing of the waterway & 16 & 249471 & $\mathrm{n}$ \\
\hline \multirow{6}{*}{ Linear } & Re-opening or elimination of drainage & 53 & $\mathrm{n}$ & 2823 \\
\hline & Re-opening of main drainage structures & 7 & $\mathrm{n}$ & 1317 \\
\hline & Sub-catchment transfer of drainage waters & 1 & $\mathrm{n}$ & 23 \\
\hline & Local transfer of drainage waters & 4 & $\mathrm{n}$ & 537 \\
\hline & Revitalisation of the stream channel & 31 & $\mathrm{n}$ & 5816 \\
\hline & Decreasing of drainage intensity - curtain & 8 & $\mathrm{n}$ & 2647 \\
\hline
\end{tabular}




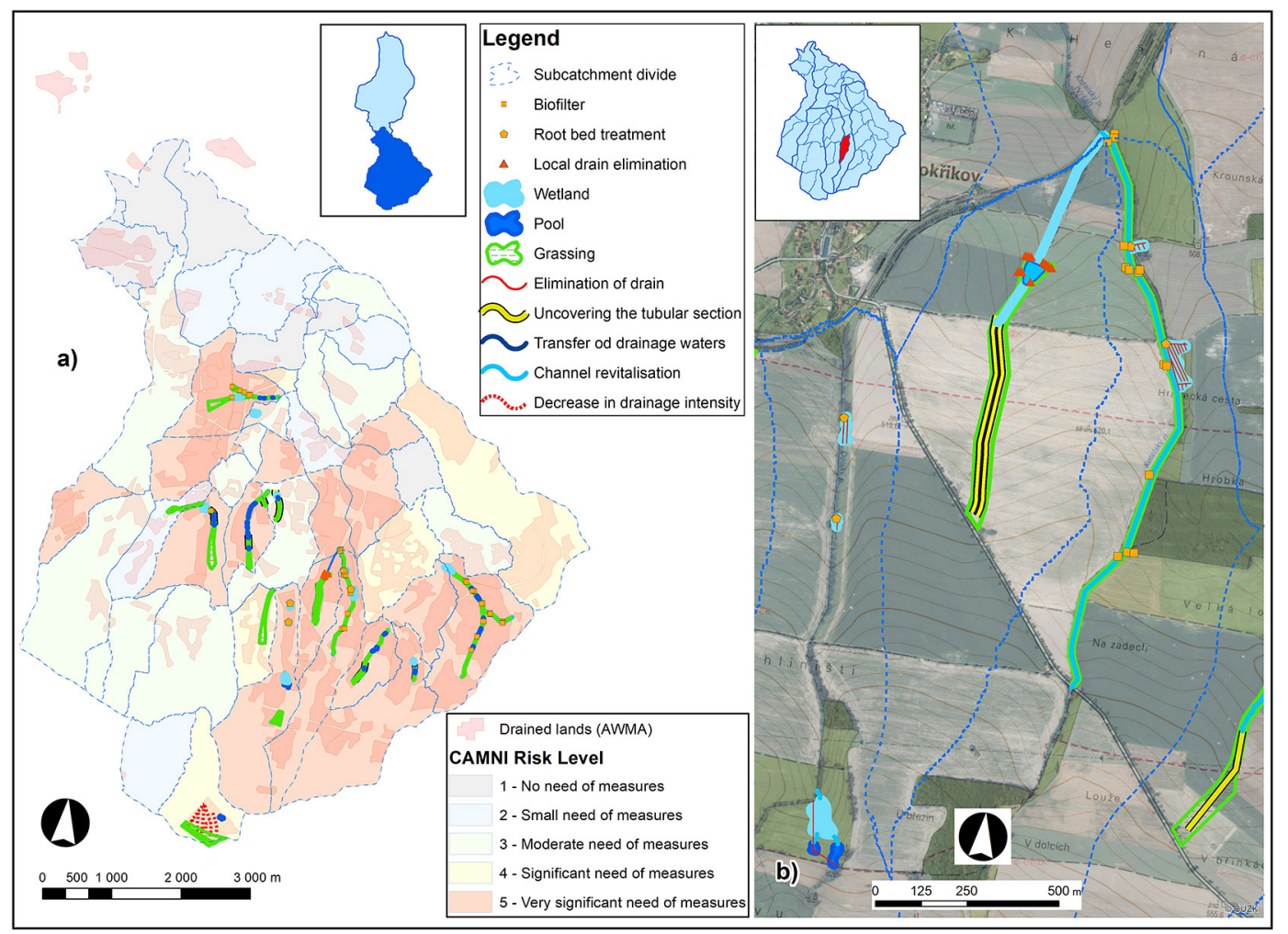

Figure 5. Overview of proposed measures; a) Placement of all proposed measures, b) Measures proposed in selected sub-catchment

has been designed. In this case, the depth of the pool is determined by the height of the earthen embankment created as a result of its excavation. As part of the pool's design, it was necessary to blind the adjacent collective drains of the downstream DDF to prevent unwanted drainage of the pool via the retained collective drains along the pool and under the pool. The spacing of the plugs (11 $\mathrm{m}$ on the left side of the pool and $33 \mathrm{~m}$ on the right side) was designed to respect the elevation of the disturbed drain, thus eliminating the risk of the water being diverted to the surface. The drains affected by the pool will be closed by means of newly constructed drainage outlets, which are located below the level of the maximum elevation or above the pond.

In the section of the MDF below the pool (northern part), the revitalisation of the channel was proposed. More precisely specified - the measure known as "Modification of the original design parameters of the MDF" has been proposed in the form of a slight loosening of the channel route to respect the slope conditions of the area. The purpose of this measure is to raise the level of the bottom of the MDF while changing the route of the artificial channel so that in the relatively limited space between the drains, the requirements for bringing the character of the MDF closer to the natural flow are applied as much as possible. The new channel respects the functions of the adjacent drains and maintains the number of drainage outlets. The outlets are moved downstream to increase the level of the MDF.

To improve the function of the main measures proposed, additional measures have been proposed throughout the site. These measures consist mainly of vegetation strips along the linear elements. The more significant vegetation elements (tree species) already present in the proposal area have been respected and preserved. Additional measures in the vicinity of the flow-through pond consist of a grassed strip around the water area and a service road designed for the maintenance of the pond.

\section{Estimate of the effectiveness and financial evaluation of the proposed measures}

The effectiveness of the proposed systems of measures, estimated according to the methodology described above, is presented in the Table 7 for the individual sub- catchments concerned. The reduction of the nitrate-nitrogen load, as the most important pollutant from 
drainage runoff, ranges from $18 \%$ to $80 \%$ in the individual sub- catchments, depending on the number of proposed measures, their type, and especially on the size of the area affected by the measures. In absolute terms, the reduction in $\mathrm{N}-\mathrm{NO}_{3}$ load would range from $130 \mathrm{~kg} /$ year to $12500 \mathrm{~kg} /$ year in the sub-catchments affected by the proposed measures. For the whole pilot area, it was estimated that there would be a reduction of $44350 \mathrm{~kg} /$ year of nitrate-nitrogen $(48 \%)$ leached to the surface water bodies after the measures implementation.

The costs of the construction of measures in the 14 selected sub-catchments of the Žejbro pilot site are shown also in the Table 7. The total cost of construction of all the proposed measures would be EUR 1.32 million and for the particular sub-catchments from EUR 13 941to 341853. Average costs for implementation measures proposed would be EUR 96700 . The cost of reducing the year load of $\mathrm{N}-\mathrm{NO}_{3}$ was estimated as EUR 30. In particular sub-catchments, these costs varies from EUR 6 to EUR 286. The above extreme happened in the atypical sub-catchment 74 , where a very costly artificial wetland has been designed targeting more to the ecological stability than to nitrogen removal. Generally, to reduce nitrate nitrogen load from agricultural lands by $1 \%$, EUR 27880 is needed.

The financial benefits of measures are very difficult, if not virtually impossible, to quantify.
Dealing with the functions to improve water retention and accumulation in the landscape. It is reported that the value of retaining $1 \mathrm{~m}^{3}$ of water in the landscape is approximately EUR 20 per year [Hönigová et al., 2012]. As regarded to water quality, estimated costs of water treatment plants (regeneration salt and wastewater disposal) for reducing nitrate concentrations from $50 \mathrm{mg} / 1$ to $15 \mathrm{mg} / \mathrm{l}$ are around EUR 0.15 and for reducing nitrate concentrations from $100 \mathrm{mg} / 1$ to $43 \mathrm{mg} / 1$ even EUR 0.25 per $1 \mathrm{~m}^{3}$ (according to information from water companies). Reduction in nitrogen loads would also save money for farmers. The price of $1 \mathrm{~kg}$ nitrogen as both as nutrient in soil or as part of fertiliser varies about EUR $2[\mathrm{Fa}-$ biany et al., 2020].

Despite of all above mentioned benefits it can be said that the proposed measures are not self-financing from the financial point of view, and the financial benefits do not cover the expected costs of their maintenance. On the other hand, the proposed measures also have societal and ecological benefits which can serve as a public service for the whole society. When taken this benefits into account, make the measures suitable for implementation when co-financed from public budgets, including their annual maintenance. To effectively solve the problem of funding the measures, it is possible to include the design of these measures in the process of land consolidation or watershed planning.

Table 7. Estimate of the effectiveness of the measures and the costs of their implementation in selected 14 most vulnerable sub-catchments

\begin{tabular}{|c|c|c|c|c|c|c|}
\hline \multirow{2}{*}{$\begin{array}{l}\text { Sub- } \\
\text { catchment }\end{array}$} & \multicolumn{2}{|c|}{ Nitrate nitrogen load (kg/year) } & \multicolumn{2}{|c|}{ Decrease in $\mathrm{N}^{-\mathrm{NO}_{3}}$ load } & \multicolumn{2}{|c|}{ Costs for measures implementation } \\
\hline & Recent & After implementation & (kg/year) & (\%/year) & Total (EUR) & $\begin{array}{l}\text { For decrease } \mathrm{N}_{-} \mathrm{NO}_{3} \\
\text { load per } 1 \mathrm{~kg}(\mathrm{EUR})\end{array}$ \\
\hline 72 & 16066 & 9256 & 6810 & 42 & 84539 & 12 \\
\hline 74 & 715 & 584 & 130 & 18 & 37241 & 286 \\
\hline 85 & 4095 & 1728 & 2367 & 58 & 80905 & 34 \\
\hline 86 & 1676 & 601 & 1075 & 64 & 53358 & 50 \\
\hline 91 & 6568 & 3721 & 2847 & 43 & 82477 & 29 \\
\hline 92 & 3275 & 2326 & 949 & 29 & 29826 & 31 \\
\hline 93 & 3068 & 611 & 2458 & 80 & 62704 & 26 \\
\hline 94 & 3340 & 2860 & 479 & 14 & 13941 & 29 \\
\hline 98 & 3475 & 1970 & 1504 & 43 & 77964 & 52 \\
\hline 99 & 16887 & 4426 & 12461 & 74 & 341853 & 27 \\
\hline 101 & 10536 & 5421 & 5114 & 49 & 255213 & 50 \\
\hline 102 & 7055 & 4407 & 2648 & 38 & 14628 & 6 \\
\hline 104 & 5773 & 1890 & 3883 & 67 & 125982 & 32 \\
\hline 105 & 2183 & 567 & 1616 & 74 & 67429 & 42 \\
\hline Total & 84711 & 40350 & 44344 & 48 & 1328060 & 30 \\
\hline
\end{tabular}




\section{CONCLUSION}

This paper has introduced a new approach for prioritization and designing measures for main and detailed drainage facilities. This approach consists of (I) selecting suitable sites using the CAMNI method; (II) obtaining information on drainage facilities in the area of interest; (III) conducting a field survey and water quality monitoring; (IV) designing appropriate systems of measures; and (V) analysing the estimated costs of the proposed measures.

Bringing this approach to practical use could help solve the currently heightened need to address the issue of agricultural drainage structures, where current extremes in rainfall distribution highlight some of the negative effects of intensive landscape drainage such as the accelerated runoff of water from the landscape and the introduction of pollution from surface agricultural sources to receiving streams.

\section{Acknowledgments}

This work was funded by the projects TH02030397 "New approaches to the revitalisation of the main drainage facilities in relation to drainage systems in term of water retention in the landscape" supported by the Czech technological Agency (TAČR), QK21010341 "Optimisation of a set of measures for agricultural catchment areas in the framework of the land consolidation process" supported by the National Agricultural Research Agency (NAZV) by a project H2020 OPTAIN - OPtimal strategies to retAIN and re-use water and nutrients in small agricultural catchments across different soil-climatic regions in Europe; Grant agreement ID: 862756, and by the research project of the Czech ministry of agriculture MZE-RO 0218. Authors wish to thank Mrs. Rebecca Hollinger for language corrections.

\section{REFERENCES}

1. Addy K., Gold A.J., Christianson L.E., David M.B., Schipper L.A., Ratigan N.A. 2016. Denitrifying bioreactors for nitrate removal: A meta-analysis. Journal of Environmental Quality, 45(3), 873-881. http://dx.doi.org/10.2134/jeq2015.07.0399

2. Brown C., Van Beinum W. 2009. Pesticide transport via sub-surface drains in Europe. Environmental Pollution, 157, 3314-3324.
3. Carstensen M.V., Hashemi F., Hoffmann C.C., Zak D., Audet J., Kronvang B. 2020. Efficiency of mitigation measures targeting nutrient losses from agricultural drainage systems: A review. Ambio, 49(11), 18201837. http://dx.doi.org/10.1007/s13280-020-01345-5

4. Dollinger J., Dagès C., Bailly J.-S., Lagacherie P., Voltz M. 2015. Managing ditches for agroecological engineering of landscape. A review Agronomy for Sustainable Development, 35(3), 999-1020.

5. Fabiani S., Vanino S., Napoli R., ZajíčekA., Duffková R., Evangelou E., Nino P. 2020. Assessment of the economic and environmental sustainability of Variable Rate Technology (VRT) application in different wheat intensive European agricultural areas. A Water energy food nexus approach. Environmental Science and Policy, 114, 366-376.

6. Fučík P., Hejduk T., Peterková J. 2014. Quantifying water pollution sources in a small tile-trained agricultural watershed. Clean Journal, 42, 698-709. http://dx.doi.org/10.1002/clen.201300929

7. Fučík P., Zajíček A., Duffková R., Kvítek T. 2015. Water Quality of Agricultural Drainage Systems in the Czech Republic - Options for Its Improvement, In Research and Practices in Water Quality; Lee T.S.; InTech: Rijeka, 239-262. http://dx.doi. org/10.5772/59298. ISBN 978-100 953-51-2163-3.

8. Fučík P., Zajíček A., Kaplická M., Duffková R., Peterková J., Maxová J., Takáčová Š. 2017. Incorporating rainfall-runoff events into nitrate-nitrogen and phosphorus load assessments for small tiledrained catchments. Water, 9, 712. http://dx.doi. org/10.3390/w9090712

9. Goswami D., Kalita P.K., Cooke R.A.C., Mcisaac G.F. 2009. Nitrate-N loadings through subsurface environment to agricultural drainage ditches in two flat Midwestern (USA) watersheds. Agricultural Water Management, 96, 1021-1030.

10. Hirt U., Hamman T., Meyer B.C. 2005. Mesoscalic estimation of nitrogen discharge via drainage systems. Limnologica - Ecology nad Manegement of Inland Waters, 35(3), 206-219.

11. Hönigová I., Vačkář D., Lorencová E., Melichar J., Götzl M., Sonderegger G., Oušková V., Hošek M., Chobot K. 2012. Survey on grassland ecosystem services - Report of the European Topic Centre on Biological Diversity. Nature conservation agency of the Czech Republic, 78.

12. Janglová R., Kvítek T., Novák P. 2003. Soil infiltration capacity categorization based on geoinformatic processing of soil survey data. Soil and Water Scientific Studies, 2, 61-81.

13. Kozelová I., Špulerová J., Miklósová V., Gerhátová K., Izakovičová Z., Kalivoda H., Kalivodová M., Kanka R. 2020. The role of artificial ditches and their buffer zones in intensively utilized agricultural landscape. Environmental Monitoring 
and Assessment, 192(10), 656. http://dx.doi. org/10.1007/s10661-020-08610-w

14. Kroger R., Holland M.M., Moore M.T., Cooper C.M. 2008. Agricultural drainage ditches mitigate phosphorus loads as a function of hydrological variability. Journal of Environmental Quality, 37(1), 107-113. http://dx.doi.org/10.2134/jeq2006.0505

15. Kulhavý Z., Doležal F., Fučík P., Kulhavý F., Kvítek T., Muzikář R., Soukup M., Švihla V. 2007. Management of agricultural drainage systems in the Czech Republic. Irrigation and Drainage, 56, 141149. http://dx.doi.org/10.1002/ird.339.

16. Kulhavý Z., Fučík P., Tlapáková L., Soukup M., Čmelík M., Hejduk T., Marták P., Stehlík M., Pavel M. 2012. Guidelines for eliminating negative functions of drainage facilities in the landscape to support applicants for subsidies in the Priority Axes 1 and 6. Part A: Methodological guide for Czech ministry of environments, part B: Detailed analysis of the issue. (In Czech), Prague, 242.

17. Kulhavý Z., Fučík P. 2015. Adaptation Option for Land Drainage Systems Toward Sustainable Agriculture and the Environment: A Czech Perspektive. Pol. J. Environ. Stud., 24(3), 1085-1102. http:// dx.doi.org/10.15244/pjoes/34963

18. Kulhavý Z., Pavel M. Kudrnová L., Fučík P., Dostál M., Zajíček A., Pelíšek I., Krása J., Duffková R. Novák P., Hejduk T. 2017. Catalogue of agricultural area source reduction measures for Type A action sheets (including drainage systems) with respect to critical area and watershed categorization. Prepared in the framework of the study for the Vltava River Basin State Enterprise. Preparation of Measure Sheets A of agricultural pollution sites for sub-basin plans, Prague, 163. (In Czech).

19. Kvítek T., Žlábek P., Bystřrický V., Fučík P., Lexa M., Gergel J., Novák P., Ondr P. 2009. Changes of nitrate concentrations in surface waters influenced by land use in the crystalline complex of the Czech Republic. Physics and Chemistry of the Earth, 34(8-9), 541-551. http://dx.doi.org/10.1016/j. pce.2008.07.003

20. Lavrnić S., Nan X., Blasioli S., Braschi I., Anconelli S., Toscano A. 2020. Performance of a full scale constructed wetland as ecological practice for agricultural drainage water treatment in Northern Italy. Ecological Engineering, 154, http://dx.doi. org/10.1016/j.ecoleng.2020.10592

21. Lüderitz V. 2004. Towards sustainable water resources management: A case study from Saxony-Anhalt, Germany. Management of Environmental Quality, 15(1), 17-24. https://doi. org/10.1108/14777830410513568

22. Novák P., Fučík P., Kulhavý Z., Zajíček A., Pelíšek I., Ptáčníková L., Dostál T., Krása J., Bauer M., Pavel M., Rosendorf P., Krátký M., Kvítek T.
2016. Preparation of Type A Action Sheets for agricultural pollution sites for sub-basin plans. Methodological guidance - identification of critical points and categorisation of sites at risk of pollution from surface and subsurface agricultural sources for the whole territory of the Czech Republic in detail for the preparation of Type A action sheets. Certified methodology. VÚMOP, v.v.i., Prague, 69. (in Czech)

23. Pavel M. et al. 2019. Catalogue of MDF revitalization measures. Output of the project New approaches for revitalization of main drainage facilities with connection to drainage systems in terms of water retention in the landscape, SWECO Hydroprojekt a.s., Prague, 55. (in Czech).

24. Povilaitis A., Rudzianskaite A., Miseviciene S., Gasiunas V., Miseckaite O., Živatkauskiene I. 2018. Efficiency of drainage practices for improving water quality in Lithuania Transactions of the ASABE, 61(1), 179-196. http://dx.doi.org/10.13031/trans.12271

25. Stoate C., Báldi A., Beja P., Boatman N.D., Herzon I., van Doorn A., de Snoo G.R., Rakosy L., Ramwell C. 2009. Ecological impacts of early 21st century agricultural change in Europe - A review. Journal of Environmental Management, 91(1), 22-46. http:// dx.doi.org/10.1016/j.jenvman.2009.07.005

26. The EU Directorate General Environment. Catalogue of Natural Water Retention Measures - online: http://nwrm.eu/measures-catalogue

27. The World Overview of Conservation Approaches and Technologies. Global Database on Sustainable Land Management - online: https:/www.wocat.net/ en/global-slm-database

28. Tlapáková L., Žaloudík J., Kulhavý Z., Pelíšek I. 2015. Use of remote sensing for identification and description of subsurface drainage system condition. Acta Universitatis Agriculturae et Silviculturae Mendelianae Brunensis, 63(5), 1587-1599. http:// dx.doi.org/10.11118/actaun201563051587

29. Tlapáková L. 2017. Agricultural drainage systems in the Czech landscape - Identification and functionality assessment by means of remote sensing. European Countryside, 9(1), 77-98. http://dx.doi. org/10.1515/euco-2017-0005

30. Váchal J., Váchalová R., Vlčková Z., Koupilová M., Moravcová J. 2006. Anthropoecological zoning of farmland as a basis for land adjustment design. Ekológia, 25, 145-161.

31. Vymazal J., Sochacki A., Fučík P., Šereš M., Kaplická M., Hnátková T., Chen Z. 2020. Constructed wetlands with subsurface flow for nitrogen removal from tile drainage. Ecological Engineering, 155. http://dx.doi.org/10.1016/j.ecoleng.2020.10594

32. Worrall F., Burt T., Adamson J. 2003. Controls on the chemistry of runoff from an upland peat catchment. Hydrological processes 17(10), 2063-2083. 
33. Zajíček A., Pomije T., Kvítek T. 2016. Event water detection in tile drainage runoff using stable isotopes and a water temperature in small agricultural catchment in Bohemian-Moravian Highlands, Czech Republic. Environmental earth sciences, 75, 1-13. http://dx.doi.org/10.1007/s12665-016-5561.

34. Zajíček A., Fučík P., Duffková R., Maxová J. 2017. How Does Targeted Grassing OfArable Land Influence Drainage Water Quality And Farm Economic Indicators? International Journal of Environmental Impacts, 1(3), 344-352. http://dx.doi.org/10.2495/ EI-V1-N3-344-352
35. Zajíček A., Fučík P., Kaplická M., Liška M., Maxová J., Dobiáš J. 2018. Pesticide leaching by agricultural drainage in sloping, mid-textured soil conditions - the role of runoff components. Water Science and Technology, 77(7-8), 1879-1890. http:// dx.doi.org/10.2166/wst.2018.068

36. Zajíček A., Dostál T., Krása T., Hejduk T., Fučík P., Kulhavý Z., Bauer M., Pelíšek I., Jáchymová B., Devátý J., Rosendorf P., Pavel M., Vojtěchovský T., Kyzlíková E. 2018. Atlas of non-point pollution of waters in the Vltava River Basin. VÚMOP, Prague. atlaspvl.vumop.cz. 